\title{
日本近海における海産付着動物の移入について*
}

\author{
荒 川 好 満** \\ (昭和 55 年 10 月 1 日受理)
}

\section{On Alien Immigration of Marine Sessile Invertebrates into Japanese Waters}

\author{
Kohman Y. ARAKAWA \\ Hiroshima Fisheries Experimental Station, \\ Ondo-cho, Aki-gun, Hiroshima 737-12
}

(Received October 1, 1980)

近年，海外との往来がひんぱんになるにつれて，外国 産動植物のわが国への渡来も, 目立って増加の傾向にあ る。陸上の動植物については, すでに詳しい調査がすす められ，正・高島 (1942)，宮下 $(1970, ' 77)$ その他に よる包括的な報告があるが，海産生物については，一般 の耳目にふれ難いせいもあって, 断片的な記録が散見さ れるだけで，まとまった報告はない。

ことに付着性の海産無脊椎動物の場合, 船舶や漂流物 などの媒介で海洋を往来する機会がひんぱんであるか

ら，活かの海産生物にくらべると，本来の生物地理学的 境界をこえて, 遠隔の海域への移住の可能性も一層高い 筈である。にもかかわらず，この方面の報告が予想外に 少ないのは, 前述の理由のほかに, わが国近海の付着生 物についての分類学的研究の歴史が, 欧米諸国に比して 浅く, 明治以前には, 付着生物相の正確な記録が充分に なされていなかったことにもよると思われる。

筆者は, 峑殖力キと競合する海産付着生物の防除に関 する生物学的研究にたづさわるらち, 水産生物の蒙る生 物災些 (biodeterioration) の多くが, 海外から侵入した 付着生物などによってひき起されている事実に着目し, 広岛付近のカキ着殖場ばかりでなく、ひろく、わが国近 海の州化付着生物一般の動向にも留意し，記録の収集や 調查を進めてきた。

ここでは,これまでに知られた水産上有害な付着動物 (fouling animals) のわが国近注への移入の経緯，その

* 1979 年 8 月, 第 14 回太平洋学術会議 XIV Pacific Science Congress（ハバロフスク Khabarovsk) における講演内容 “Marine sedentary invertebrates invaded into Japanese waters" を大 幅にふえんしたものである。

** 広島紧水産試験場
後の分布や経過, 水産生物あるいは生物相への影響など を明らかにし，あわせて，これまで積極的にわが国へ移 植が試みられた欧米産カキ類など, 水産上有用な付着動 物についてもふれることとしたい。

本文に入るにさきだち，それぞれの専問の立場から有 益な助言やご教示, あるいははげましをいただいた山口 寿之 (東大理地質), 堀越增興・梶原武 (東大海洋研), 時岡隆 (京大名誉教授), 関哲夫・小野寺弘（カキ研）, 滝㦑 (京都産業大学), 波部忠重・小坆昌也・鈴木克美 (東海大海洋), 今島実 (国立科博), 馬渡静夫 (付着生物 研), 河原辰夫（玉野測量設計）, 長田武正, 谷田尃治, 鳥海表, 星野孝治（広大臨海）および故内海冨士夫の各

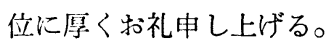

\section{日本近海の帰化付着動物}

これまでの調査によって，わが国近海に渡来したこと が明らかな海産付着動物には, つぎの 13 種がかぞえら れる(表 1$)$ 。これらのらち，第 2 次大戦後の 30 余年間 に渡来したものが 9 種類に達し, 全体の約 $70 \%$ を占め ている。

このように海外から侵入した生物が，新天地に根をお ろすには，いくつかの生態的条件を満たす必要がある。 その一つは, 新しい環境に, その種にふさわしい生態的 地位を確保することである。それには，生物自身，環境 の変化に幅広い適応性をそなえていることが前提で，塩 分や水温の变化，あるいは污染などに抵抗性があり，産 卵期が長くて繁殖力が旺盛などの要件があげられる。そ してもし, そこに有力な競合者や捕食者, あるいは天敵 などによる抑圧がなければ, 往々異常発生して猛威をふ るい，新天地の生物相や水産生物にはなはだしい影響や 
表 1. 日本近海の帰化付着生物分類表

Systematic list of marine sessile invertebrates immigrated into Japanese waters

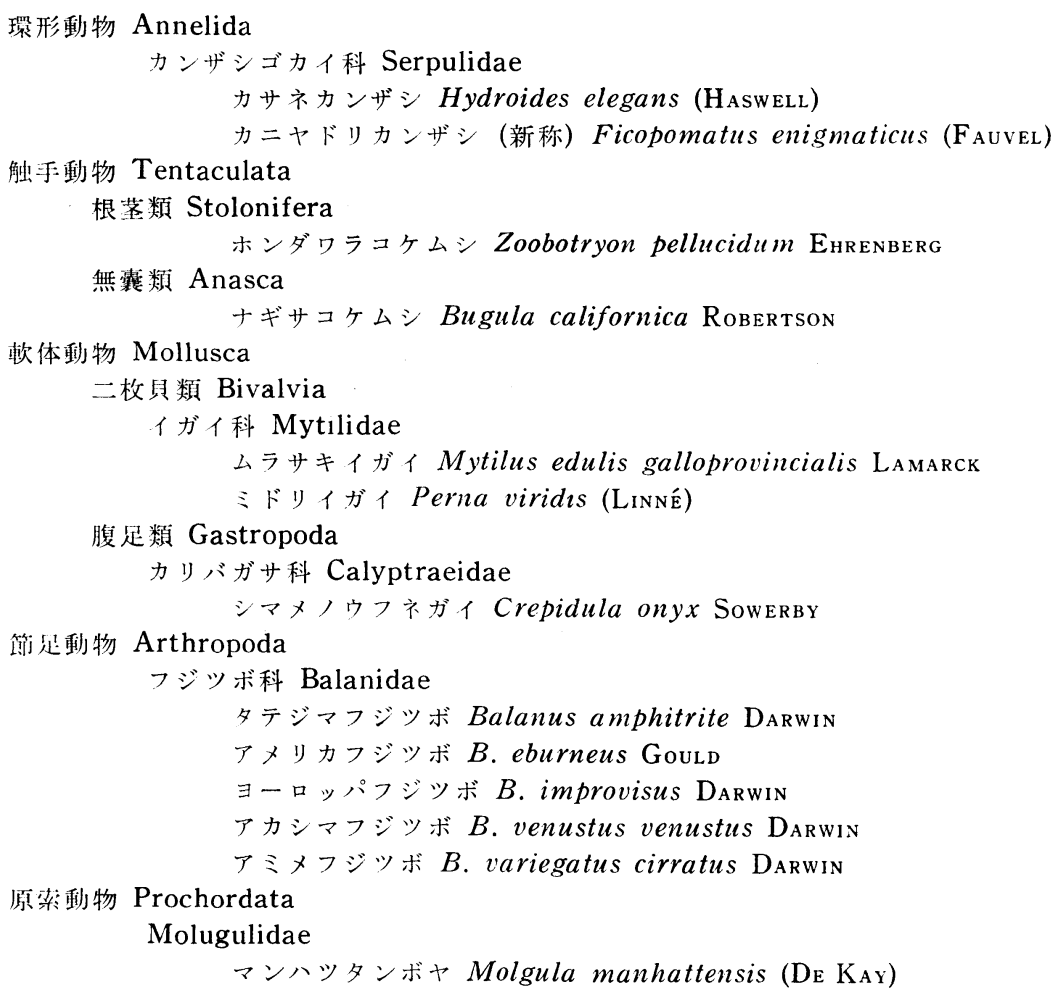

被害をおよぼすことがある。

1) カサネカンザシ* Hydroides elegans (HASWELL)

本種はオーストラリア近海，八ワイ，東南アジア海 域，大西洋，地中海に分布する管棲多毛類の 1 種で (IмA Jima, 1976), 1936 年, 紀伊白浜で発見されたのが日 本近海における最初の記録である(FAUVEL, 1936)。 初, F AUvel は, これをH. norvegica (GUNnerus) と記

* 本種は 1969 年, 広島湾で異常発生した当時は, 大 西洋，地中海に分有する $H$. norvegica に问定さ れた. その後, 広泉湾などに分布する内湾性のも のはH.elegans とするのが正しく, H.norvegica は外洋性の種類で, 内海には分布しない旨, さき の同定結果を訂正された. 最近では, H. norvegica の分布が各種の文献に記載されてはいるものの, 果して本邦近海に分布するものかどうか疑わしい といらのがここれまで本種に関して筆者に示され た今帛実博士の見解の変遷である。これは分類学 の進歩にともなつてひき起される過渡的な混乱で, 止をを得ないこ上上思われるが，参考までに付記 しておく.
載したが，後年，IмаJima（1976）によって当該標本が研 究され，H. elegans に訂正された。広息付近では，1966 尔秋頃から, 広島湾奥部のカキ養殖場で目立はじめ, 1969 作には広島湾を中心に愛媛, 大分, 和歌山など, 瀬戸人 海一円に異常発生し，荃殖中のカキ・アコヤガイなど に，かってない大きな被害を与えた。これによって，㕕 島産羕殖カキの作柄は, 平年の約 $60 \%$ に落ちこみ, 被 害額は実に 30 億円以上にも達したといわれる。その 後，広島付近では，1２年おきに小規模な異常発生をく り返したが，徐々に至微し，最近では平衡状態を保って いる。本州中南部以南の内湾に分布定着している。

2）カニヤドリカンザシ（新称）Ficopomatus enigmaticus (F $\mathrm{AUVEL}$ )

本種は 1966 年に㡐山県児易湾 (人工の\%水湖)で下 田哲資氏（現長崎大）によって採集されたのが，わが目 に扮ける最初の出現記録である(今島私信, 1980)。綂い て，1969年には，カサネカンザシとほぼ時をを同じくし

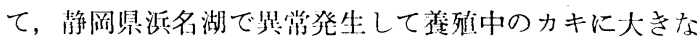


被害を与えた。本種は塩分の変化にきわめてひろい適応 性を示し, 塩分 1〜33\%o の範囲で着生し, 同じく 5 30\%oでもっとも速やかに成長をとげるという。1921 年 にフランス大西洋岸ノルマンディーの海岸で発見された が，現在では世界の温熱帯海域にひろく分布するように なり,コスモポリタン（汎世界的）な種類と目されてい る。わが国では, 児島湾, 浜名湖のほか, 隅田川々口, 石垣島川平湾などから報告されている。

なお, 北アメリカ大西洋岸原産のオウギガ二の 1 種 Rhithropanopeus harrisi は, 本種の石灰質の棲管内に 好んで共生し, 1953年, デンマークのコペンハーゲン港 で初めて本種が発見された折, このカ二も, ともに移住 していたことが伝えられている(WoLfF, 1954)。

3) ホンダワラコケムシ Zoobotryon pellucidum EHRENBERG

本種は, 北アメリカ太平洋原産で, わが国近海からは 1942年に三重県浜島の真珠湌殖笺と神奈川県三崎の船底 から報告されている(馬渡, 1952)。また，これよりさき， 今世紀初頭に，千葉県館山で丘浅次郎氏が採集した慓本 中に本種がまじっているのを A. RoBERTSON 女史が確認 し未発表のリストに記載されていたともいわれる（MA WATARI，1952）ので，あるいは，この方がわが国最初の 出現記録かも知れない。最近では，わが国沿岸では，ご く普通に見ることができる（山村, 1972）。

4) ナギサコケムシ Bugula californica RoBERTSON 北アメリカ太平洋岸原産で, 現在わが国近海の沿岸干 潮線下のいたるところに分布している (MAWATARI, 1952; SAKAI, 1971)。

最近の馬渡（私信，1980）の見解によれば, 上述のコ ケムシ類について，発見の記録はあるものの，古くから わが国近海に産しなかったといら証拠はない。しかし， 系統分類学的生物地理学の立場をはなれ，しいて，大胆 な割り切り方をすれば，あるいは，つぎにあげるような ものも，移入種と見てもよいかも知れないとしてい る :

シロヒゲコケムシ Crisia eburneo-denticulata $\mathrm{S}_{\mathrm{MITH}}$ スエヒロクダコケムシ Tubulipora flabellaris

(FABRicius)

ハナザラコケムシ Lichenopora radiata ORTMANN アミメヒダコケムシ Membranipora savartii

(Audouin)

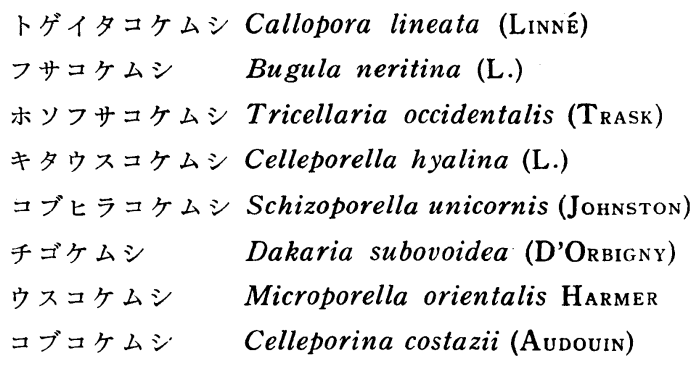

5) ムラサキイガイ Mytilus edulis galloprovincialis

\section{LAMARCK}

本種はもともと, 英伀海峡, 地中海, 北アメリカ大西 洋岸などに分布し，わが国近海への渡来は外国航路の船 舶によるといわれる。一説によると，1923 年（大正 12 年）の関東大震災の後, 復旧資材として大量に輸入した 木材についてわが国にもたらされたのが，その後 5〜10 年のあいだに各地へひろがったといわれる。欧州産のム ラサキイガイとよばれるものには, 北欧産の Mytilus edulis LINNÉ 々南欧地中海産の M.e. galloprovincialis の 2 型があり, わが東北地方, 北海道, 千島に分布する のは前者に, 東北地方以南のものは後者の特徵にそれぞ れ一致する。これが別種であるか，地方的品種であるの か, 専問家のあいだで議論が斗わされたが, 結局, 仙者 間に natural hybrid ができるらしいことや isozyme 分析の結果などから, 地理的亜種と考えるのが孚当で, 北方型を M. edulis, 南方型を M.e. galloprovincıalis として区別することに落着くようである（堀越私信， 1979)。なお，北海道，千島など，わが国の subarctic 海域に分布する北方系の品種は, 明治中期にはすでに, その存在が知られていたようで，この 2 つのタイブは， それぞれ異なる年代に違った経路でわが近海に侵入し， ひろがっていったものと思われる。本種は欧米では古く から,カキとともに sea food の雄として食用に供され, 盛んに養殖も行なわれてきたが，わが国ではむしろ，他 の養殖生物の競合者として有害視されている。わが国最 大のカキ養殖場をかかえた広島では，1965年頃までは， 湾西部の一部海域の表層に限って付着が認められ, 程殖 カキへの影響もとりたてて云うほどのこともなかった が, その後, 湾内の富栄養化がすすむにつれて, 湾全域 にひろがり，付着層も表層から深層 $(0 \sim 10 \mathrm{~m})$ におよ び，深刻な被害をもたらすようになった。

6) ミドリイガイ Perna viridis (LINNÉ) 本種は台湾以南のインド太平洋に分布し，わが|⿴囗十正で 
は, 1967 年, 兵庫県揖保郡御津町尼谷（相生港）で最初 に発見された（鍋島，1968）。発見当初は 1 日に 100 二 以上も採集されるほどであったのが，1969年以降，忽然 と姿を消し，その後，わが国近海からは報告されていな い。相生港は污染が進む 1970 年以前には，真珠養殖場 として利用されていたので, 当時, 宇和易から持ち込ま れた養殖アコヤガイに付着して運ばれてきたのか，ある いは外航船によって直接もたらされたのか, その辺の事 情はさたかではない。

\section{7) シマィノウフネガイ Crepidula onyx SowERBY}

本種は北アメリカ太平洋岸に分布するカリバガサ科の 付着性腹足類の 1 種である。わが国では, 1968年神奈川 県三浦半島悠浦海岸で発見されたのが最初の記録である (間瀬, 1969)。その後, 房総半島一円, 伊豆大島や, 関東 南部以北の太平洋岸各地から報告され，伊豆大島波浮港 では産卵例も報じられている（青木, 1975, ’78; 西村,
1975)。1976年, 福井県小名浜および照島から報告され たが,これは，日本海側における最初の出現記録であ る。その後, 1980年 7 月, 広島県沼隈郡横島近海からも 採集されており，これは，わが国での分布の南限である (荒川, 1980)。

本種は発見当初, ネコゼフネガイ C. fornicata (LiNNÉ) (北アメリカ大西洋岸原産) に誤って同定されたが, 後に訂正された経緯がある（間瀬, 1971；波部, 1972）。 このネコゼフネガイは後に述べるマンハッタンボヤとと もに北米東岸における養殖カキの最大の競合者と目さ れ，イギリス沿岸にも侵入し，スコットランド，コーン ワールの養蠣場で猛威をふるった記録がある。一方, シ マメノウフネガイは原産地では, 主として他の巻貝類の 殸の表面に幾重にも重なり合って付着し，その排泄物な どを摂取するといら片利共生的生活を営んでいる。これ までに移住先のわが国近海で, 本種の付着の対象にえら ばれたものには, 貝類, とくに腹足類が圧倒的に多数を

表 2. わが国近海におけるシマメノウフネガイの既知付着対象種

Known host species of the southern california slipper shell, Crepidula onyx, which has invaded into Japanese waters

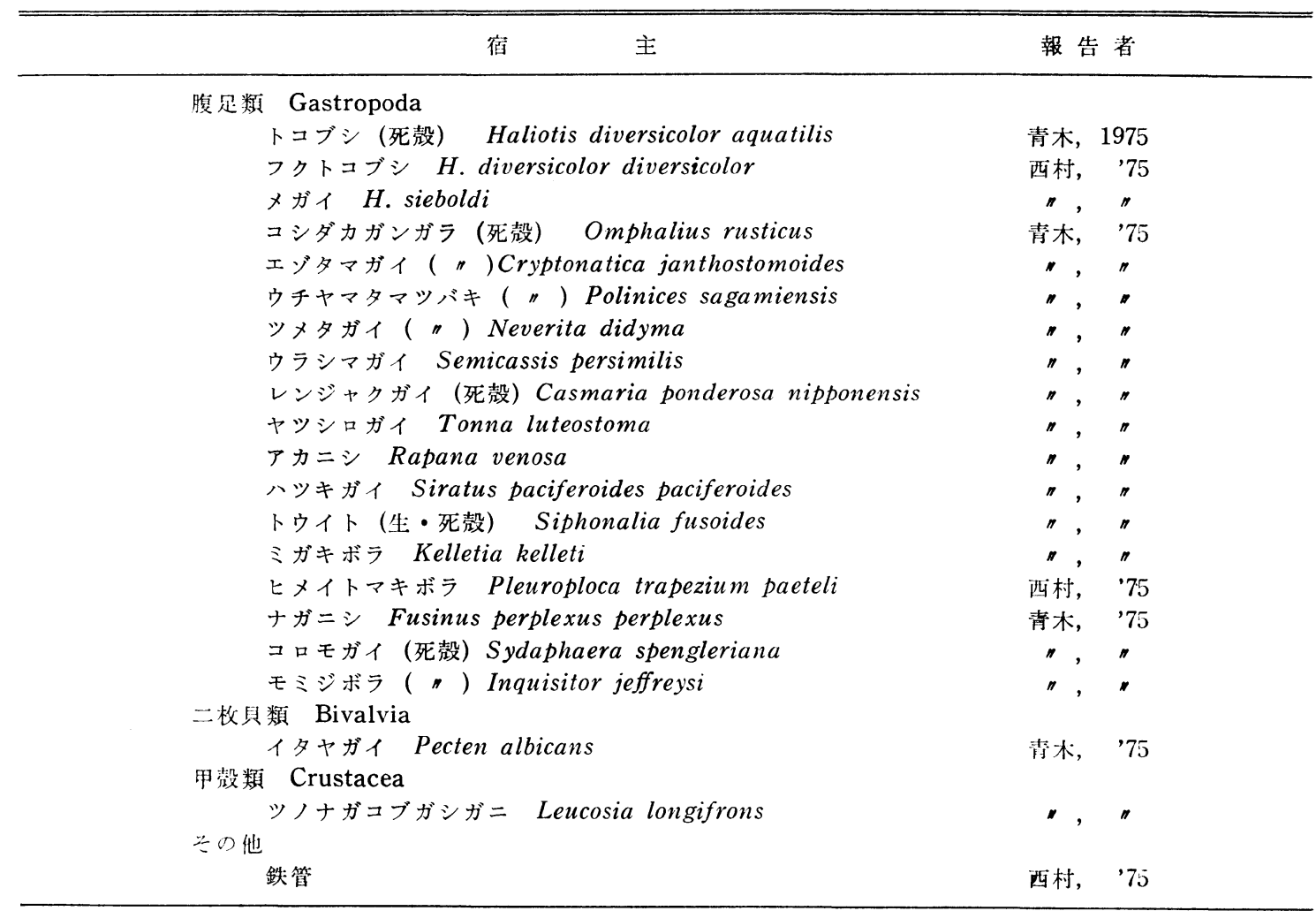


占わ，二枚貝に付着するものはあってもごく稀である。 また例外的にカ二の甲や鉄管などの地物についている例 も苃告されている (表2)。

\section{8) タテジマフジッボ Balanus amphitrite DARWIN}

本種は, もともと熱带太平洋起源で, 漂流物などにつ いたのが黑潮にのってわが国近海へ運ばれ定着したもの 之想像される。わが国の貝塚その他の遗跡から出土する 本種の化石の層序学的研究によれば, 少なくも, およそ 3, 000 年前には, 寸でにわが国へ渡来していたものと推 测される (山口, 1979)。現在では, 外洋水の影響の少な 、塩分の低い内海や内湾に多く, 海水の污れや富栄養化 がすすむにつれ，在来のサラサフジッボ B. reticulatus UтіNом⿰ にかわって分布を拡大し, 津軽海陕以南のわが 国沿岸の港湾に定着している。最近では, 世界の温熱帯 水域に繁殖し, 海中構造物や水産・電力関係施設などに 少なから被害を与えている。

\section{9) アメリカフジッボ B. eburneus Gould}

北アメリカの大西洋岸起源といわれ，わが国では1964 位, 山形県加茂港で最初に, ついで翌 1965 年, 新潟県 作渡の加茂湖 (汽水湖) で発見されている。馬渡によれ ば, 本種ははじめ, 米国軍艦によって佐世保軍港へ侵入 したものが，黒潮支流にのって北上，分布を拡大したと されている(S AKAI, 1971)。また, 一説には, 最初, 広島 に侵入定着したものが, 1955 年頃, 種がキに付着して加 茂湖へ運ばれ, 日本海沿岸にひろまった可能性の方がつ よいともいわれる（内海私信, 1968)。本種は, かなり以 前から, 広島湾内のカキ養殖施設（筏, ブイ, 垂下連） に優占的に付着しているのが見られるが，干潮時の干出 に抵抗が弱いせいか，岸壁などでは低潮線より上には見 られない。また, 1963〜'64 年にかけて, 全国の主要港 湾の付着生物調査を行なった馬渡（1967）によれば，佐 世保, 長崎, 舞鶴, 玉野拈よび鹿児島の各地で本種の生 息が確認され，現在では，ほぼわが国の沿岸各地に分布 している。

\section{0) ヨーロッパフジッボ B. improvisus DaRwIN}

本種はヨーロッパ大西洋岸の内湾の土着種であるが, 後しだいに北アメリカ東岸に移住し,ささらは同西海岸 へ侵入した。また，黑海や紅海へも進出し，第二次大戦 後は南半球へも分布を抎大し, オーストラリア近海でも 生息が報告されている。わが国では，1957〜'58 年に英 虞湾付近ではじめて発見され(河原, 1963), その後, 三
河湾, 浜名湖, 熊野灘沿岸, 紀伊水道, 堺港, 長崎, 佐 世保, 玉野, 相生, 深江, 鳥羽, 油壶, 佐渡, 穴道湖な ぞ, 関東北部以南の各地にひろがっていった（内海, 1966，'67; 馬渡，1967; 北見・小関，1971; 伊賀，1973) 本種は低塩分の海水を好むので, 内湾低塩性の在来種で あるシロスジフジッボ B. albicostatus PILSBRY との競 合が予想されたが，本種もアメリカフジッボと同様，干 出に極端に弱いため, 低潮線を境に上方にシロスジフジ ッボが，下方に本種が，それぞれ生活空間をわかち合っ て棲みわけている（宮下，1977）。

11) アカシマフジッボ B. venustus venustus DARWIN 本種は, わが国では, 1968年に佐渡ヶ島の相川で発見 されたのを皮切りに, 翌 1969 年に内浦湾音海からも報 告されている(UтіломI, 1970; 安田, 1970)。また，第二 次大戦後, アフリカ西海岸（あるいはクェート）から㷌 航した外航船の船底から採集されたことがあるが，当時 はまだ，日本沿岸から知られていなかったので，比較的 最近になってから移入されたものと思われる。

12) アミメフジッボ B. variegatus cirratus $\mathrm{D}_{\mathrm{ARWIN}}$ 本種は熱帯太平洋起源で, オーストラリアからインド 洋北岸, マレーシア, 台湾, フィリピン, 九州西岸, 朝 鮮へかけて分布する。わが国では, 1936 年, 有明海沿岸 の三角で，腹足類の一種アカ $=シ$ Rapana venosa (VALENCIENNES) の殸に付着しているのが UTINOMI (1967) により，はじめて報告された。侵入経路やその後の経過 など, 詳細については, 今後の調査にまたねばならぬ が，本種は通常，潮間帯や高潮亚帯に生息する軟体動物 の殼や砂質の海底に棲むそのほかの底生生物に付着して いることが多いといわれる。

13) マンハッタンボヤ Molgula manhattensis (DE $\left.\mathrm{K}_{\mathrm{AY}}\right)$

本種は北アメリカ大西洋原産のホヤ類の 1 種で, 1972 年, 広島県竹原市近郊の塩田跡池の污れのいちじるしい 塩分変化のはげしい潮だまりの中から，はじめて発見さ れた (Токіока \& KADO 1972)。原産地の北米東岸では, マサチューセッツ州 (Massachusetts) からチェサピー ク湾 (Chesapeak Bay) へかけて分布し，ここでも低 塩分で污染のすすんだ海水中に好んで生息するといわれ (VAN NAME, 1945)，養殖カキにとっては，さきにあげた ネコゼフネガイとともに最大の競合者に名をつらね、こ れによる被害はいちじるしいものがある。わが国では, 
その後, 浜名湖, 東京湾へと北方へ分布を拡大しつつあ ることが報じられている（中内・梶原，1979），しかし， さいわいにもまだわが国では，本種によるカキその他の 養殖生物の被害は報告されていない。

以上のほか，現在までのところ，確実な証拠はない
が, ニウレイボヤ Ciona intestinalis (LINNÉ) やツシロ桨 ヤStyela plicata (Lesueur) などは，おそらく永い作月 を経て「世界化」し，わが国へ侵入したものであろうと 考えられている (時岡私信，1979）。上記 13 種の原産地 や移入経過をまとめて就 3 に示す。

表 3. 日本近海の帰化付着生物一覧（昭和 55 年 9 月現在）

Summary of marine sessile invertebrates immigrated into Japanese waters (1980 September)

\begin{tabular}{|c|c|c|c|c|}
\hline 類 & 原 産 & $\mid$\begin{tabular}{|l} 
最初の発見地・発見| \\
年
\end{tabular} & その後の経過・分布 & 凟料・文献 \\
\hline \multicolumn{5}{|l|}{ 環形動物 Annelida } \\
\hline $\begin{array}{l}\text { カサネカンザシ Hydro- } \\
\text { ides elegans }\end{array}$ & $\mid \begin{array}{l}{[\text { オーストラリア, 東 }} \\
\text { 南アシシア海域, 大四 } \\
\text { 洋, 地中海] }\end{array}$ & $\begin{array}{r}\text { 紀伊白浜 (和歌山県) } \\
1936\end{array}$ & 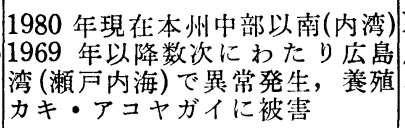 & 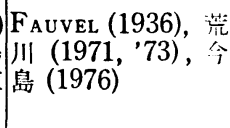 \\
\hline $\begin{array}{l}\text { カニヤドリカンザシ (新 } \\
\text { 称) Ficopomatus enig. } \\
\text { maticus }\end{array}$ & ヨーロッパ大西洋岸 & 児帠湾（岡山県） & 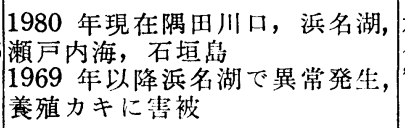 & $\begin{array}{l}\text { 木下・平野 (1977) } \\
\text { 会島 }(1979, \text { 私信 } \\
\text { '80) }\end{array}$ \\
\hline \multicolumn{5}{|l|}{ 触手動物 Tentaculata } \\
\hline $\begin{array}{l}\text { ホンダワラコケムシ Zo- } \\
\text { obotryon pellucidum }\end{array}$ & 北アメリカ太平洋汗 & 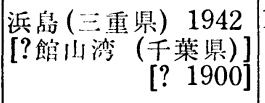 & 1980 作現在, 本邦沿详各地 & $\begin{array}{l}\text { 馬渡 }(1952, ' 67), \\
\text { SaKAI (1971) }\end{array}$ \\
\hline $\begin{array}{l}\text { ナギサコケムシ Bugula } \\
\text { californica }\end{array}$ & $?$ & $?$ & 1980 作現在, 本州太平洋岸 & \begin{tabular}{|l} 
馬渡 (1967), S SAKA1 \\
(1971)
\end{tabular} \\
\hline \multicolumn{5}{|l|}{ 軟体動物 Mollusca } \\
\hline $\begin{array}{l}\text { ムラサキイガィ Mytilus } \\
\text { edulis galloprovincialis }\end{array}$ & 大西洋，地中海 & $\begin{array}{l}\text { 金沢，諸磯 (神奈川 } \\
\text { 県) } \\
1928(?)\end{array}$ & 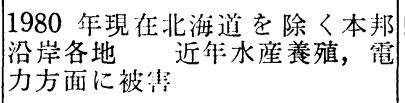 & 内橋 (1939) \\
\hline$\underset{\text { viridis }}{ミ \text { リガイ Perna }}$ & $\mid \begin{array}{l}\text { 印度太平洋（東南ア } \\
\text { ジア） }\end{array}$ & 相生港（兵庫紧) 1967 & 1969 年以降消減 & 鍋点 $(1968,75)$ \\
\hline $\begin{array}{l}\text { シマメノ ウフネガィ } \\
\text { Crepidula onyx }\end{array}$ & 北アメリカ太平洋 & 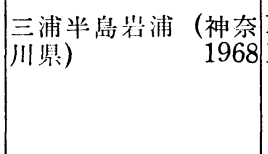 & 1980 年現在, 広島, 関東南部伊 & 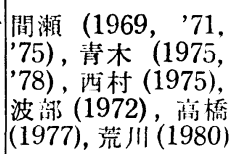 \\
\hline \multicolumn{5}{|l|}{ 節足動物 Arthropoda } \\
\hline $\begin{array}{l}\text { タテジマフジツボ } \\
\text { anus amphitrite }\end{array}$ & $\begin{array}{l}\text { 印度太平洋（東南ア } \\
\text { ジア） }\end{array}$ & $\begin{array}{l}(\text { 日本 }) \\
(\text { 約 } 3,000 \text { 年前 })\end{array}$ & $\begin{array}{l}1980 \text { 年現在, 津軽以南の本邦各 } \\
\text { 地 }\end{array}$ & 山口(1976, '79, 私 \\
\hline $\begin{array}{l}\text { アメリカフジッボ } B . \\
\text { eburneus }\end{array}$ & 北アメリカ大西洋吽 & $\mid \begin{array}{cc}\text { 加茂港（山形県） } \\
1964 \\
\text { 加茂湖（新潟県） } \\
1965\end{array}$ & 1980 年現在，本邦沿䒚各地 & $\begin{array}{l}\text { 内海 }\left(1966,{ }^{\prime} 68\right), \\
\text { SAKAI }(1971), \text { 昌 } \\
\text { 海 }(1967)\end{array}$ \\
\hline $\begin{array}{l}\exists \text { ロッッパフジッボ } \\
\text { improvisus }\end{array}$ & $\exists$ ーロッパ大西洋恸 & 英㲊湾（三重桨） & 1980 年現在, 関東北部以南各地 & 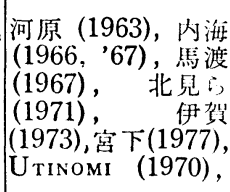 \\
\hline $\begin{array}{l}\text { アカシマフジッボ } B . \\
\text { venustus venustus }\end{array}$ & 大阿洋 & $\left|\begin{array}{r}\text { 佐渡相川 (新潟県) } \\
1968\end{array}\right|$ & & Utinomi \\
\hline $\begin{array}{l}\text { アミメフジッボ B. vari. } \\
\text { egatus cirratus }\end{array}$ & $\begin{array}{l}\text { 印度太平洋（東南ア } \\
\text { 汇ア） }\end{array}$ & 有明海 $\quad 1939$ & $\mid \begin{array}{l}\text { 1980年現在，暖流の影響のつよ } \\
\text { 、内湾 }\end{array}$ & Uтімомı (1968) \\
\hline 原索動物 Prochordata & & & & \\
\hline Molgula manhattensis & 北アメリカ大西洋器 & $\mid$\begin{tabular}{|l} 
竹原塩田跡池（広島 \\
鼠）
\end{tabular} & 1980 华現在, 瀬戸内海, 泜名湖, & $\begin{array}{l}\text { TOKIOKA \& KADO } \\
(1972), \text { 中内・暒原 } \\
(1979)\end{array}$ \\
\hline
\end{tabular}




\section{欧米産力キのわが国への移植例}

明治中期頃から，わが国のマガキの種苗がアメリカ・ カナダの太平洋岸あるいはヨーロッパ各国などへ移出さ れた例は，一々枚学に樶がなく，現在では水産貿易上確 固たる地歩を占めるにいたっている。しかし一方，海外 の優良なカキ種苗を積極的にわが国へ移植し，その繁殖 をはかろうとする試みは，戦前にはほとんど例がなく， 戦後も故今井丈夫東北大教授らの努力で，主にカキの遗 伝育種や種苗生産研究の材料として移入された例がある だけである。そのあるものは現在まで継続飼育され，ま た養殖も行なわれている。

ここでは，有用付着珄二枚貝のわが国への移植例とし て，関係者から寄せられた私信などをたよりに，その顛 末を記録にとどめておきたい(表 4)。

1) ヨーロッパ(ヒラ)ガキ(フランスガキ) Ostrea edulis LINNÉ (イタボガキ科 Ostreidae)

本種はノルウェーからイベリア半島，地中海をへて黑 海へかけてのヨーロッパ沿岸に分布するが, 1952 年, 今 井教授はコリンガ (P. KorRINGA) 博士を通じて Bergen op Zoom 産のもの 69 個体を入手し，以後，束北大学 女川臨海実験所において継代凔育するとともに, 1961 年 には，その一部を宮城県本吉郡舞根の財団法人カキ研究 所に移して種苗生産研究を開始，さらに1966年には，青 森県水産増殖センターへも移して人工生産種苗による養 殖が事業化され，現在にいたっている (IMAI et al. 1953; 関私信, 1979)。

2) オリンピアガキ Ostrea lurida CARPENTER（イタ ボガキ科 Ostreidae)

本種は北アメリカ太平洋岸アラスカからカリフォルニ ア南部へかけて分布，1948年，アメリカ合采国シアトル (Seattle), キルシーン (Quilcene) の魚介類实験所 (Shellfish Laboratory) のリンゼー氏 (C. LiNDESEY) を通じて，2 3 年生カキ 43 コ（平均殼長 $3.5 \mathrm{~cm}$ ) を 宮城県女川町（東北大女川実験所） へ移植，1950～’52 年にかけて種苗生産実験に供された。1953 年 5 月には， これによって得られた人工種苗を北海道サロマ湖および 有珠湾に移植，さらに，1961年には前記カキ研究所に移 植して，以後，現在まで継代飼育し(ImAI et al., 1954), 人工種苗による養殖が続けられている（関私信，1979）。

表 4. 欧米産力キ類の日本近海への移植例一覧

Summary of oysters transplanted into Japanese waters from abroad

\begin{tabular}{|c|c|c|c|c|c|}
\hline 類 & 原 産 & 移植年 & 移 植 & 移植後の経過 & 資料 - 文献 \\
\hline $\begin{array}{l}\exists \text { ヨッパ(ヒラ)ガキ } \\
\text { (フランスガキ) Ostrea } \\
\text { edulis }\end{array}$ & 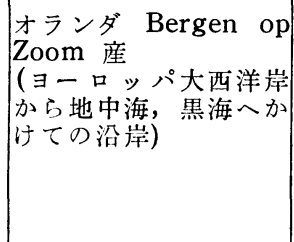 & 1952 & \begin{tabular}{|l|} 
宫城県女川町 (東 \\
北大学農学部女川 \\
実験所) \\
\end{tabular} & $\begin{array}{l}\text { 同実験所で継代飼育するほ } \\
\text { か, } 1961 \text { 年 } 1 \text { 部をカキ研 } \\
\text { 究所 (舞根)へ移して本格的 } \\
\text { 種苗生産事業に着手, 以後 } \\
\text { 現在まで国内市場へ出荷 } \\
1966 \text { 年青森県水産增殖セ } \\
\text { ンターへも分僙し企業化を } \\
\text { はかる }\end{array}$ & $\begin{array}{l}\text { Imai et al (1953) } \\
\text { 関 (私信, 1979) } \\
\text { (KORRIGNGA によ } \\
\text { る) }\end{array}$ \\
\hline $\begin{array}{l}\text { オリンピ ピアガキ } O \text {. } \\
\text { lurida }\end{array}$ & 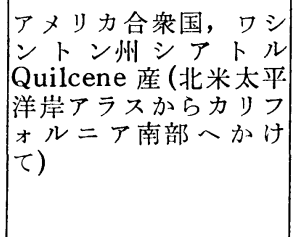 & 1948 & 闹上 & $\begin{array}{l}1950 \text { ’52 年にかけて女川 } \\
\text { で種苗生産実験に着手し, } \\
1953 \text { 年実験で得た種苗を } \\
\text { 北海道サロマ湖と有珠湾へ } \\
\text { 移植 } \\
1961 \text { 年カキ研へも種苗分 } \\
\text { 椌し, 以後種苗生虐ならび } \\
\text { に継代飼育 }\end{array}$ & $\begin{array}{l}\text { 関（私信，1979) } \\
\text { IMAI et al. (1945) } \\
\text { (LINDESEY による) } \\
\end{array}$ \\
\hline $\begin{array}{l}\text { ポルトガルカキ Cras- } \\
\text { sostrea angulata }\end{array}$ & $\mid \begin{array}{l}\text { オランダ Bergen op } \\
\text { Zoom 産 (ヨーロッパ } \\
\text { 大西洋に分布) }\end{array}$ & 1952 & 同上 & $\begin{array}{l}1961 \text { 年にカキ研へ一部を } \\
\text { 移植し，1971 年まで種苗 } \\
\text { 生産 } \\
1971 \text { 年種苗を浜名湖(静岡 } \\
\text { 県)へ移植 } \\
\text { 現在は母貝種苗とも死減 }\end{array}$ & $\begin{array}{l}\text { 関（私信，1979) } \\
\text { IMAI et al. (1953) } \\
\text { (KoRRINGAによる) }\end{array}$ \\
\hline $\begin{array}{l}\text { アメリカガキ } C \text {. vir. } \\
\text { ginica }\end{array}$ & 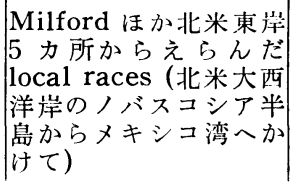 & 1956 & 同上 & $\mid \begin{array}{l}1959 \text { 年に移植母貝は全滅 } \\
\text { 数年後には，種苗も死減 }\end{array}$ & $\begin{array}{l}\text { 関(私信，1979) } \\
\text { (LoOSANOFF によ } \\
\text { る) }\end{array}$ \\
\hline
\end{tabular}


3) ポルトガルカキCrassostrea angulata (LAMARCK) (イタボガキ科 Ostreidae)

本種は, フランス, イギリス，ポルトガルなどのヨー ロッパ沿岸に分布。ヨーロッパヒラガキとともに, 1952 年に 51 コを女川へ移植し，以後，継代飼育。1961年に その一部をカキ研究所へ移植し，1971年まで種苗生産実 験に供し, 同年, 人工種苗の一部を静岡県水産試験場浜 名湖分場を通じて浜名湖へ移植したが, 現在は母貝も死 隇し，種苗生産も行なわれていない(IMAI et al. 1953; 関私倍, 1979)。

4) アメリカガキ (バージニアガキ) Crassostrea vir. ginica (GmeLIN) (イタボガキ科 Ostreidae)

本種は北アメリカ東海岸の土着種で, カナダのノバス コシア半島からメキシコ湾へかけて分布。わが国へは, 1956 年, アメリカ合衆国ミルフォード実験所 (Milford Laboratory) のルーサノフ博士 (V. L. Loosanoff) を通 じて, 表 5 の 5 地域の地方的品種 (local races)を松島 と女川に移植したが，母貝は 3 年間で全減し，それから 得た種苗も数年間で減びた。また，母貝の一部をカキ研 へ移植, 種苗生産実験に供したよらであるが, これも死 隇して, 今はない(関私信, 1979)。

表 5. 日本に移植したアメリカガキの地方的品種 (関私信より)

Local races of Crassostrea virginica transplanted into Japan

\begin{tabular}{lccc}
\hline \multicolumn{1}{c}{ 地域 } & 移植カキ種 & 移植数 \\
\hline G-Francis Beavan & 母 & 貝 & 189 \\
Milford Laboratory & 種 & 苗 & 374 \\
Pensacola Oyster & 母 & 貝 & 146 \\
James River & 種 & 苗 & 750 \\
Saim Mary's River & \multicolumn{2}{c}{$"$} & 317 \\
\hline
\end{tabular}

地域は上から下へ，北から南の順に配列

\section{文献}

青木茂男 (1975). シマメノウフネガイの付着状況. ちりぼたん，8(6)，146.

青木茂男 (1978). ネコゼフネガイの入手とシマメ ウフネガイの比較.ちりぼたん，10(2)，32-34.

荒川好満 (1971). 1969 年広島湾に異常発生した管楼 多毛類の 1 種カサネカンザシによる養殖カキの被嚄 について。貝類学雑誌, 30(2), 75-82.

荒川好满 - 久保田久次 (1973). 養殖力キ付着生物の
防除に関する研究一I，広鼠湾に抢けるカサネカサ ネカンザシの分布・季節変化. 広島水試研報, 4 , 13-17.

荒川好満 (1974). 音戸付近の養殖場で発生したムラ サキイガイによるカキの被㫪。広島水試研報， 5 , 35-37.

エルトン (川那部浩哉ほか䚿) (1971), 侵略の生態学. $223+x v$. 思索社, 東京.

Fauvel (1936). Annelides polychedes du Japon. Mem. Fac. Sci., Kyoto Imp. Univ. (B), 12, 4192.

波部忠重 (1972).シマメノウフネガイとネコゼフネ ガイ.ちりぼたん， 7(3)，49-50.

ten Hove, H. A. (1974). Notes on Hydroides elegans (Haswell, 1883) and Mercierella enigmati. ca FAuvel, 1923, alien serpulid polychaetes introduced into the Netherlands. Bull. Zool. Mus., Univ. Amsterdam, 4(6), 45-48.

ten Hove, H. A. \& J. C. A. Weerdenburg (1978). A generic revision of the brackish-water serpulid Ficopomatus Southern 1921 (Polychaeta: Serpulidae), including Mercierella Fauvel 1923, Sphaeropomatus TREADwell 1934, Mercierellopsis Rioja 1945 and Neopomatus Pillai 1960. Biol. Bull., 154, 96-120.

伊賀哲郎 (1973). 突道湖・中海抢よび神西湖のフジ ツボ類. 山陰文化研紀要，13，59-69.

Imai, T., S. Sakai \& H. Okada (1953). Transplantation of European flat oyster, Ostrea edulis, into Japanese waters and its breeding in tanks. Tohoku Jour. Agr. Res., 3 (2), 311-312.

Imai, T., S. Sakai, H. Okada \& T. Yoshida (1954). Breeding of the olympia oyster in tanks and culture experiments in Japanese waters. Tohoku Jour. Agr. Res., 5 (1), 13-25.

Imajima, M. (1976). Serpulinae (Annelida, Polychaeta) from Japan. I. The genus Hydroides. Bull. Nat. Sci. Mus., Ser. A (Zoology), 2(4), 229-248.

今島 実 (1979). 付着生物の種類查定法 (1) 管棲多 毛類. 付看生物研究, 1(1), 29-35.

梶原 武・平野礼次郎 (1975). 海産付着生物の生態. 「海洋学講座 9, 山本護太郎編, $213+\mathrm{v}$. 東大出版 会, 東京」185-203

Kawahara, T. (1963). Invasion into Japanese waters by the European barnacle Balanus improvisus Darwin. Nature, 198, 301.

木下秀明・平野礼次郎 (1977). 管捿多毛類の生態々 浮遊幼生期の飼育. 海洋科学, 9(4), 31-36.

北見健彦 (1968)，佐渡島および票島沿岸産の夢脚類. 新潟県生物教育研究会誌, No. 4, 68-74

北見健彦・小関恒雄 (1971)。佐渡および新潟沿岸に 㧍ける外国産フジツボの採集補遗. 採集と飼育, No 7, 170-171.

䦎瀬欣弥 (1969a)。相模で採れたネコゼフネガイ。ち 
りぼたん，5(6)， 156-157.

間瀬欣弥 $(1969 \mathrm{~b})$. ネコゼフネガイ追録. ちりぼた儿 $5(7), 200$.

間瀬欣弥 (1971)。相模のネコゼフネガイは「シマメ ノウフネガイ」が妥当。ちりぼたん，6(7)， 155.

閒瀬欣弥 (1975a). シマメノウフネガイ・その後. ち りぼたん，8(6)，143-145.

閒瀬欣弥 $(1975 b)$. シマメノウフネガイ繁殖状況調查. ちりぼたん，8(6)，145.

Mawatari, S. (1952). Bryozoa of Kii Peninsula. Publ. Seto Mar. Biol. Lab., 2 (2), 261-288.

Mawatari, S., H. Kitamura \& Y. Kawashima (1968). Propagation of invaded barnacles by ships. Proc. Jap. Soc. Syst. Zool., No. 4, 24-30.

馬渡静夫 (1967). 我国港湾污損の生物学的研究一I. 研究概要. 资源研彙報, No. 69, 87-114.

馬渡静夫・林一朗 (1974). 小田原に抢ける浸漬試 験板に着生したフジッボ類. 東水研々報, No. 77, 1-21.

馬渡静夫・北村晴男・川島康代 (1968)。移入フジッ ボによる分布拡大一一淡青丸の場合. 動物分類学会 誌, No. 4, 24-30.

宫下和喜・高橋秀男 (1970). 外国から来た動植物. 第 1 法規，東京.

宮下和喜 (1977)。悱化動物の生態学—侵略と適応 の歴史．講談社ブルーバックス，No. 460, 213.

鍋島結子 (1975). 瀬戸内海のミドリイガイその後. ちりぼたん，8(5)，102.

鍋島結子 (1968). ミドリイガイについて. かいなか ま, 2(4)，15-20.

中内光昭・暒原 武 (1979). ユウレイボヤモドキと マンハッタンボヤ。付着生物研究，1(1)，45.

西村和久 (1975). 伊豆大島にもシマメノウフネガイ。 ちりぼたん，8(5)，108-109.

丘英通 - 高島春雄 (1942). 帰化動物. 北方出版社.

SakaI, T. (1971). Notes from the carcinological fauna of Japan (IV). Res. Crust., 4 (5) , 138-156. 杉谷安彦 (1969). 瀬戸内海でとれたミドリイガイに ついてちりぼたん，5(5)，123-125.

杉谷安彦 (1968). ミドリイガイの生棲について.か いなかま，2(3)，27-29.

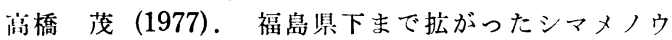
フネガイ。ちりぼたん，9(5)，109.

Tокіока, T. \& Y. Kado (1972). The occurrence of Molgula manhattensis ( $\mathrm{DE}_{\mathrm{E}} \mathrm{K}_{\mathrm{Y}}$ ) in brakish water near Hiroshima, Japan. Publ. Seto Mar. Biol. Lab., 21(1), 21-29.

内橋 潔 (1939)。 日本列島に於けるムラサキイガイ (Mytilus edulis LINNÉ) の新分布. 兵庫水武試験報 告, No. 1, 4-8.

内海冨士夫 (1966)。 外国産フジッボの最近における 日本一の移入. 動物分類学会誌, No. 2, 36-39.

Utinomi, H. (1967). Comments on some new and already known cirripeds with emended Taxa, with special reference to the parietal structure. Publ. Seto Mar. Biol. Lab., 15 (3), 199-237.

Uтіломі, H. (1970). Studies on the cirripedian fauna of Japan IX. Distributional survay of thoracic cirripeds in the southeastern part of the Japan Sea. Publ. Seto Mar. Biol. Lab., 17 (5) , 339-372.

Van Name, W. G. (1945). The north and south American ascidians. Bull. Amer. Mus. Nat. Hist., 84 (476), 31.

Wolff, T. (1954). Occurrence of two east American species of crabs in European waters. Nature, 174, 188-189.

山口寿之 (1976). フジッボ類の最近の分布変化. 昭 和 51 年海産付着動物の生態に関するシンポジウム 講演要旨集, 5 .

山口寿之 (1979). 付着動物の種類查定法 (2) 日本の 海岸にすむフジッボ類について. 付着生物研究, $1(1), 37-44$.

山村豊 (1972)。真珠養殖漁場に打汀る付着生物の 生態学的研究一II. 国立真珠研報, No. 16, 20382051.

安田 徹 (1970). 福井県下における沿朔付着性污損 生物の生態研究——内浦湾音海沿岸におけるフジッ ボ類 4 種について。 日水誌，36(10)，1007-1016.

追 記：本論文校正中に，西インド諸嶌起源の二枚貝の 1 種イガイダマシ Mytilopsis sallei (RécLUz) (カワホ トトギスガイ科 Dreissenidae=マゴコロガイ科) が, 静闭県清水港内から発見されたことを知った。詳細は, 石橋・小坂（本誌，2(1)，p. 60）および波部（ちりぼた 几, 第 11 巻第 3 号) にゆゔるが, 本種は M. leucophaea (CONRAD) と同種の可能性もあるとのことである(波部, 小坂私信， 1980 による). 